\title{
Social Geographies of Education: Looking Within, and Beyond, School Boundaries
}

\author{
Damian Collins*1 and Tara Coleman ${ }^{2}$ \\ ${ }^{1}$ University of Alberta \\ ${ }^{2}$ University of Auckland
}

\begin{abstract}
Schools have received less attention from geographers than institutions such as the clinic and the hospital - despite the fact that, for most people, encounters with sites of medicine are rarer than encounters with sites of education. Indeed, schools are central to the geographies of children and young people, and to the organization of much family life. Moreover, they play a central role in shaping social identities. In this article, we provide an introduction to, and review of, the literature that takes seriously the sociospatial dimensions of schooling. Our discussion is organized around two central themes: first, the organization of school space, and the ways in which it is implicated in issues of power, and the reproduction of preferred identities; second, the linkages between schools and broader communities, and what these tell us about the values and aspirations attached to schooling. In both respects, we suggest, schools are places of considerable social and political significance.
\end{abstract}

\section{Introduction}

Schools are central to the social geographies of everyday life: they are one of the few institutions that can be found in almost every urban and suburban neighbourhood, and with which almost every individual has meaningful, sustained contact at one or more points in their lives. Children are generally required to spend a considerable proportion of their waking hours in school, and the time geographies of parents are often structured around the school day. In this sense, schools - particularly, those which are part of public systems of education (known variously as 'state' or 'public' schools - although the latter term has an opposing meaning in the UK) can be considered truly 'common' places. Indeed, in many parts of Canada and the USA the first public schools were labelled 'common schools'. This distinguished them from their denominational predecessors, and signalled that they were nation-building institutions, which sought to create common citizens from ethnically, linguistically and religiously diverse populations (Moore 2000; Sweet 1997). Inherent in this connection 
between nation-building and public education was the view - still widely shared today - that schools can shape not only children's knowledge and behaviour, but also their identities.

Such perceptions, combined with public funding, help to underscore the social significance of schools for households, neighbourhoods and the nation-state. Yet, in spite of this prominence, schools have remained relatively underexamined within geography. They have received far less attention than the clinic and the hospital - traditional places of concern for medical and health geographers, especially those interested in 'the intersections of the institutional and the geographical' (Philo and Parr 2000, 513) - despite the fact that, for most people, encounters with sites of medicine are considerably less routine than encounters with sites of education. Schools are central to the organization of everyday life for many families, and profoundly shape the patterns of certain social activities (e.g. commuting and holidaying), yet the geography of education has not emerged as a well-recognized subdiscipline of human geography. This said, it is possible to piece together, from disparate sources, a body of geographical research that takes schooling seriously.

In this article, we provide an introduction to, and review of, scholarship on the social-geographic significance of schools - especially, although not exclusively, studies that 'self-identify' as geographical. Our review is necessarily broad; we are concerned to identify common themes, and where possible international similarities. We suggest that while the political organization of school systems differs substantially between, and even within, countries - schools generally have common roles to play in the organization of social life, and the shaping of social identities. This argument is, admittedly, easier to make when one focuses on schools in the developed, English-speaking world - as we do here. This limitation reflects not only our own research interests and experiences to date, but also the relative paucity of English language, geographically informed research on schools outside of this context.

More specifically, our discussion is oriented around two main concerns. First, we review the literature that considers the organization of space inside schools. Themes include the behavioural norms that prevail within schools, and the ways in which these are resisted; the social significance of school grounds; the ways in which social identities are shaped by educational spaces; and the place of diversity within schools. In canvassing these topics, we see schools as particularly useful sites for examining the structure-agency tension, and the geographies of power. Second, we examine research that has highlighted the role of schools within broader communities of interest operating at various spatial scales. The link between the neighbourhood and the school is one of particular importance. Underpinned by the widespread notion that children have the right to attend the (public) school nearest to their home, this connection operates in two directions: schools often reflect the broad social characteristics of their neighbourhoods, but at the same time they play a role in shaping 
those characteristics, both directly (e.g. in terms of the education offered), but also less directly (e.g. in terms of contributing to social cohesion). The centrality of schools to much (adult-dominated) politics is also considered.

In both sections, the notion of place is highly pertinent. In the first, the school is a place - a bounded portion of geographical space within which certain rules apply and particular activities occur. Schools are highly specialized environments, which (temporarily) isolate and segregate children from wider social and spatial contexts, in order that they might be simultaneously protected from, and prepared for, adult life. Accordingly, schools have much in common with other institutional geographies - such as those associated with the prison, the hospital and the asylum - in which isolation from mainstream social life is a central organizing concept (Philo and Parr 2000).

In the second section, we emphasize that the school has a place within broader social landscapes. For example, it is often represented as part of a community - typically, a community that is coextensive with neighbourhood or school board boundaries, although it may also be constituted at the regional or national scales. Conceptualizing the place of schools in this manner is important, we argue, because debates over public education frequently take the form of struggles over the appropriate site or scale at which decisions about classroom content and curricula should be made (see, for example, Collins 2006; Witten et al. 2003).

\section{Within School Boundaries}

Schools are central sites in the lives of most children and young people of 'school age', and can usefully be thought of as their de facto workplaces. In the New Zealand context, for example, primary schools are required to open for instruction on 197 days per year, and high schools for 190, and those aged 6-16 are compelled by statute to be enrolled in formal education (which, for most, means compulsory school attendance). Even temporary absences from school on the part of young people, when not caused by illness, are legally and socially problematic, and perceived as likely precursors to academic failure and risk-taking behaviour. Yet, schools have a social significance that extends beyond simply accounting for a large proportion of children's waking hours: they also seek to produce knowledge, form identity, shape behaviour and (ultimately) structure future opportunities (Lewis 2003).

Schools are, almost invariably, relatively diverse places: they cater for children and young people of different ages, inclinations and abilities. Public schools, in particular, also reflect the degrees of socio-economic, linguistic, religious and cultural difference present in surrounding communities. In light of this diversity, one function of the public school, since its inception, has been to instil common values and knowledge in children. There is an expectation that pupils will learn not only a core set of 
academic and technical skills, but also socially appropriate knowledges and values. We consider the example of health-related knowledges below, but note here the emphasis placed on instilling values in school. Traditionally, these values have often been conservative in orientation, encompassing patriotism, punctuality, order, obedience, industry, courtesy and respect. An alternative 'progressive' framework emphasizes equality, tolerance and inclusiveness, and encourages ethical judgements independent of religious and legal authority. Tension between these frameworks has generated considerable cultural and political contestation (Hunter 1991).

Schools are, at minimum, places where children 'are compelled . . . [to] undergo a decade and more of group socialization' (Bocking 1995, 227). They also have a clear social control function: formal education tends to legitimate aspects of the status quo, and permit the exercise of freedom and choice only within relatively strict bounds (Lewis 2003; Middleton 1998). For Foucault $(1977,1980)$ the school was one of a suite of modern institutions (including the asylum, the clinic and the prison) in which individuals were monitored and categorized by experts, and subject to disciplinary power. This power is readily apparent: schools monitor pupils' movement, location, comportment and (commonly) their appearance (Fielding 2000; Middleton 1998).

School days are regulated by routines, drills and detailed organizations of time and space: pupils '. . . spend most of their weekday in a very timedisciplined environment ... where all their activities from arrival, registration and lessons, through to eating and playing, are governed by the daily rhythm of timetables and bells' (Holloway and Valentine 2003, 108). Moreover, school spaces, and the classroom in particular, are organized in ways intended to facilitate adult authority and surveillance, and aid social and behavioural control of children (see Catling 2005). As in the asylum, the internal space of the school is manipulated in the hope it will 'produce more "docile" and "proper" subjects' - although, perhaps inevitably, 'these spatial practices are not always successful' (Philo and Parr 2000, 514). While individual schools may, to various degrees, depart from dominant disciplinary modes, doing so to any degree commonly risks political and community censure for an excessively liberal (i.e. permissive) approach.

\section{NORMS AND RESISTANCE}

Schools function, in part, to (re)produce social norms. Thus, the advice and training that an individual pupil receives about future adult roles may be linked to perceptions (within the school, and society more broadly) about what is befitting for someone of his or her social background (e.g. in terms of ethnicity, socio-economic status, gender and sexuality) (Aitken 1994). As various researchers have demonstrated (e.g. Fielding 2000; Holloway and Valentine 2003), the school is an institutional space through 
which young people are both controlled and disciplined by adults, and within which distinct identities are (re)produced.

Holloway and Valentine (2003) draw on an analysis of the Information and Communications Technology education in the UK to argue that schools may reproduce dominant ideas about gender. Specifically, they found that the behavioural code and micro-geographies of the Information and Communications Technology classroom perpetuate the association between masculinity and computer skills/knowledge by facilitating greater use on the part of boys. One consequence, they suggest, is that boys were more likely than girls to favour lessons incorporating computers, and to consider computer skills vital to their future lives. This said, societal understandings of femininity were sometimes deployed to support girls opting into computing for its potential to facilitate communication with others (Holloway and Valentine 2003, 70).

Holt (2007) argues that norms relating physical, intellectual and emotional competencies are reproduced within schools through children's sociocultural relations. These relations reflect the social organization of children at school on the basis of mind-body emotional differences, as well as age, gender, ethnicity and other axes of difference. Furthermore, these relations are inherently spatial because they ultimately constitute in- and outof-placeness and produce experiences of inclusion and exclusion within the school environment. These experiences are also shaped by adult understandings and practices relating to bodily norms (Holt 2007). Those who are not considered able-bodied are sometimes excluded from certain school spaces, like the playground, because of adult concerns for their competency and possible health issues - even when the child in question has no apparent illness. Teachers often emphasize the 'normality' of nondisabled children, thereby casting those who are disabled as 'abnormal' (Holt 2003). Children who do not fulfil expectations of able-bodiedness, like those who do not meet expectations about specific levels of competence and development to be achieved by a certain age, may experience diminished opportunities to learn and participate in the school environment (Holt 2004).

In considering the relationship between schools, educational spaces and social norms, it is also important to acknowledge the ability of pupils to resist prevailing expectations - notwithstanding the potential for disapprobation by adults, and ostracism by peers. This agency can take various forms, from 'unruly' classroom behaviour to more deliberate contestation of social roles. With regards to the former, Catling $(2005,327)$ observes the enduring ability of children to 'find ways to circumvent the constructions or bounds placed on their use of space', which encompasses modifying, and subverting, the sociospatial order of the classroom. An illustrative example of the latter phenomena occurred during fieldwork conducted by the second author (Coleman 2007). At one high school, young women recounted deliberately challenging gender roles by voluntarily mixing 
with young men, taunting them with sexually explicit language, and threatening them with violence.

Contestation of gender norms has also received attention elsewhere in the literature on geographies of schooling. An instructive study by Newman et al. (2006) in an English primary school used the photovoice technique to explore the connections between playground relationships and gender, finding that boys who did not adopt hegemonic, sports-oriented masculinities often occupied a social and physical 'borderland' on the edge of the playground. Efforts to counter the bullying of at least one of these boys were undercut by (adult) arguments that he should 'toughen up' - that is, conform to the 'hegemonic masculine type' (Newman et al. 2006, 295).

Jewett's (2005) study of school buses suggested that they allowed for some relaxation of expectations regarding behaviour and socializing which typically apply within school grounds. This allowed one male pupil, for example, to spend half the bus journey with male peers of a similar age, and the remainder with a group of older girls painting his nails. Interestingly, in the context of walking school buses, the mixing of children of different ages has been viewed by parents as a positive social outcome of communal walking (Collins et al. 2008). This mixing represents a notable departure from the adult-imposed segregation of children by age that characterizes most educational spaces and activities, including even some school playgrounds (Thomson 2005). Nevertheless, the walking school bus, like the school itself, is dependent on adult control and order, and even minor challenges on the part of children (e.g. in terms of ill-disciplined walking) are met with censure.

As Jewett (2005) notes, pupils' resistance to adult-imposed norms and requirements may not ultimately pose a fundamental challenge to the structural realities of school landscapes, or to associated social categories such as gender. Rather, there is an enduring tension between relatively authoritarian school structures, and the capacity of pupils to act autonomously. This tension is readily apparent in, for example, Thomson's (2005) account of near constant adult interventions in pupils' playtime activities - where spontaneity was met with a barrage of cautions, orders and 'don't' instructions from supervising teachers. This said, ethno-geographic accounts of children's use of school grounds in other contexts have revealed richer, substantially less-controlled opportunities for play and environmental exploration (Tranter and Malone 2004).

\section{SCHOOLS' OUTDOOR SPACES}

School grounds, especially 'playgrounds' in primary schools, have become a substantive focus for geographical research in, and about, schools; scholarship on this theme has been particularly well-represented in the journal Children's Geographies since its inception in 2003. Inquiry into school grounds has offered a broad range of insights into the social and spatial 
order of education. Thomson $(2005,74)$ observes that the energy and enthusiasm commonly displayed by children in school playgrounds may belie the levels of adult control over this space, and over 'the parameters of children's physicality'. This control has historically been underpinned by discourses emphasizing the link between playgrounds and the moral and physical improvement of children - discourses that resonate in contemporary concerns for regulating schools' outdoor spaces and activities in ways conductive to children's socialization, fitness and health (see, for example, Collins et al. 2006). Accordingly, Thomson (2005, 76) concludes that while the playground affords pupils a measure of autonomy - evidenced, for example, in territorial behaviours and intentional boundarycrossings - it is ultimately 'a space conceived by adults to contain children at school'.

The theme of pupil's territoriality in school grounds has received attention in a range of contexts. In English primary schools, for example, several researchers have noted the propensity for football-playing boys to dominate central playground areas, excluding girls and other boys through physical and verbal intimidation (Catling 2005; Newman et al. 2006; Thomson 2005). This theme can be connected to the broader issue of bullying on school grounds, which is also fertile ground for geographically informed analysis. As Andrews and Chen (2006, 243) note, compulsory school attendance typically prevents victims from escaping the environment in which bullying occurs, forcing them to adopt 'spatial coping tactics ... [such as] the avoidance of likely or known encounter spaces, at times where bullies typically reside and act'. In this way, experiences of both primary schools (e.g. Newman et al. 2006) and high schools (Van Ingen and Halas 2006) may be fundamentally shaped by geographies of fear. However, such outcomes are by no means inevitable, as Tranter and Malone's (2004) examination of children's positive, non-aggressive play in green (idyllic) school environments attests.

Contemporary anxieties around childhood overweight and obesity appear to increase the significance of school grounds as valuable sites of routine physical activity. This said, researchers in both Australia (Tranter and Malone 2004) and the UK (Woolley et al. 2006) note that, at least until recently, opportunities for outdoor play were threatened by such trends as schools' shortening lunch breaks, abolishing other recesses, removing play equipment and implementing increasingly restrictive rules. On a more positive note, the public health imperative of increasing children's physical activity - as well as strong evidence linking high-quality outdoor play environments to improved social skills and educational outcomes (Tranter and Malone 2004) - is also motivating efforts to improve the quality of school grounds. The archetypal barren, hard-surfaced playground - 'so often an uninviting space, open, flat, tarmac-covered and windswept' (Catling 2005, 328) - is increasing seen as inappropriate, and attention has turned to incorporating natural features, including 
woodland, gardens and ponds, into school grounds. While the ability of schools to transform 'unimaginative school grounds comprised primarily of tarmac and cultivated grass' into more stimulating, greener environments may be closely related to their socio-economic status (Dyment 2005, 308), the potential benefits in terms of opportunities for creative, diverse and relatively conflict-free play are considerable (Tranter and Malone 2004).

\section{SHAPING CHILDHOODS}

The disciplined nature of the school, combined with the fact of statutorily compelled attendance, makes it a key site for an array of interventions intended to shape the knowledge, identities and behaviours of children (Epstein and Johnson 1998; Ruddick and Flutter 2004). Given the dominant social construction of children as 'our future', such interventions are also attempts to shape the future of society, especially at the national scale. One particularly common type of intervention is driven by public health concerns (Collins et al. 2006; Denham 1999; Lavin et al. 1992; Lynagh et al. 1997). Schools are key environments for monitoring children's health and health-related behaviour: they are sites for medical intervention (e.g. immunization), for the surveillance and monitoring of bodies, and for instruction in health-related practices (often defined in terms of hygiene and, more recently, risk minimization) (Coleman 2007; Valentine 2000). Given expectations that schools will address, and pre-empt, social problems, they can experience considerable pressure to incorporate a wide array of public health concerns (on topics ranging from obesity, to sun protection, to tobacco control, pedestrian skills and water safety) into their curricula. Related to this, expectations are that teachers will act as role models in health-regarding behaviour (cf. the tobacco smoke-filled staff rooms once common in schools).

Notions of control, disciplined behaviour and surveillance fit closely with some of the original motivations for compulsory public schooling in the mid-late 19th century. At this time, schools were seen as places that both protected children from the physical and moral threats of urbanizing and industrializing society, and protecting society from the disorder associated with large numbers of working class children (in particular) on the streets (Middleton 1998). Compulsory schooling was a way of ensuring all children experienced a childhood - that is, a time of protection from, and preparation for, a world of adult responsibilities - while also instilling respect for order and authority (Valentine 2001). The subsequent isolation of children within schools, and their removal from the public spaces of the city, strengthened social constructions of childhood as a separate, distinct phase of human development. It also helped to give rise to conceptualizations of public space as adult space (see Valentine 1996).

While free primary education has since been envisioned as a human right - in the Universal Declaration of Human Rights (article 26), the 
Convention on the Rights of the Child (article 28) and in myriad other legal documents - the irony associated with making uptake of this right compulsory for children is seldom commented on. Moreover, within school environments, children's rights appear to have limited purchase. Debates about curricula (i.e. what children will learn, and how), for example, are conducted almost exclusively by adults, in adult terms, with scant if any regard to the notion that young people are entitled to a voice in matters concerning them (Convention on the Rights of the Child, article 12). Frequently, they reflect prevailing adult anxieties (especially about the moral status of children). Unsurprisingly, such anxieties are particularly evident in debates over matters such as sexuality - where progressive arguments based on the acceptance of diversity and the rights of pupils to access a broad spectrum of sexuality-related knowledges run up against arguments founded on a mixture of moral panic and a desire to minimize the dissonance between schools and conservative homes (Coleman 2007; Collins 2006). More broadly, there is an enduring tendency for debates that are ostensibly about education and the well-being of children to be transformed into arguments reflecting other adult priorities. For example, Bradford's (2006) study of school desegregation in a northern US city found that debate was often oriented around such distinctly adult political and economic concerns as property taxes and local real estate values.

This is not to say, however, that the young are expected to have an entirely passive role in educational environments. Indeed, there is growing emphasis on pupils undertaking certain responsibilities for their own learning. Rather, the point is that the structures of school environments are almost solely adult-determined. Moreover, there is no legal requirement for schools or education professionals to answer to young people themselves, which re-affirms that this group is structurally disenfranchized and largely unable to claim meaningful participatory roles within institutional spaces and the public policy sphere (Mathews et al. 2000).

\section{DIVERSE STUDENTS, DIVERSE SPACES}

While young people may have extremely limited opportunities to shape educational spaces at the formal policy level, the influence of their presence within school spaces and upon the form of this environment must not be discounted. Young people retain some agency even in the most adult-controlled spaces. Moreover, the diversity of children's interests, behaviours, attitudes and backgrounds complicates standardized approaches to delivering the curriculum and maintaining discipline. Part of the challenge of conducting socially informed research in/on schools is achieving an analytical balance between education's 'generalising tendency to futurity', which shapes the 'discourses and practices of learning', and the desire to recognize 'the diversity of that childhoods exist' (Horton and Kraftl 2006, 83; original emphasis). This tension is also implicit within 
the classroom: Thomson (1997) notes the considerable difficulties inherent in addressing the sheer variety of interests and demands present - not to mention the many competing pressures that may stem from adults (e.g. parents, policy-makers, the media) outside the immediate school environment. Van Ingen and Halas $(2006,389,391)$ observe the challenges associated with developing and implementing 'culturally appropriate programming for Aboriginal students' in Canada, in order to address the erasure of Aboriginal identity and knowledge in many schools, and associated forms of 'resistance ... including "behavioural problems", high rates of absenteeism, dropping out, and overall lack of interest and higher than average rates of failure.'

The intersection of a multitude of social backgrounds, abilities and skills in schools, while challenging for educators, may also contribute to the (re)production of place-based identities (Lynagh et al. 1997). Evolving senses of place develop as different individuals interact with each other, and school spaces, and as a diverse range of individual and institutional actions shape the physical and pedagogic environments of schools over time. By way of example, Woolley et al. (2006) identified positive social interactions, and enduring friendships, between disabled and non-disabled children in a sample of English primary schools that had adopted appropriate policies for including disabled children in playground settings.

One promising area of social geographic inquiry connects diverse demands and competing pressures on schools to the production of 'hidden geographies' within their boundaries. It points, for example, to the creation of micro-spaces in which minority issues and interests that are excluded and rendered largely invisible within official school spaces can be acknowledged and articulated. Thus, in the context of one Canadian high school, van Ingen and Halas' (2006) observed Aboriginal students forging a collective, if stigmatized, space in the form of an outdoor smoking area adjacent to the entry doors to a programme for academically at-risk students.

Another example stems from New Zealand, where the standardized Health and Physical Education Curriculum emphasizes heterosexuality and makes little mention of alternative sexualities (Allen 2005). Heterosexuality is overwhelmingly depicted within official teaching guides employed during health classes and, because there are few guidelines designed to support teachers in meeting the needs of students of alternative sexual orientations, talk regarding homosexuality is largely absent. However, informal settings, such as fields and other common areas in which adults are absent, are frequently used by high school students to pass on knowledges and sexual health information relating to homosexuality. Consequently, these informal and largely unacknowledged sites are implicated in the communication of sexually related knowledges, and constitute a hidden geography of (teenage) sexuality within the high school environment (Coleman 2007). These spaces may provide some support for those young people situated outside 
the mainstream, although they remain marginal and largely invisible elements of the school landscape. At minimum, they underscore the point that the school environment is far from monolithic, and experiences far from uniform (Holloway and Valentine 2003).

In considering hidden and informal geographies within school environments, it is also useful to acknowledge student-centred power struggles. By way of example, Banks (2005) notes that the school hallway is more than a space in which students simply pass one another en route to classes and activities. Rather, it is a social site in which status is contested and hierarchies established. Interactions in the hallway (e.g. in the form of greetings and conversations exchanged) illustrate the social structures at work, and contribute to giving the space meaning. These meanings may complicate the adult-imposed order of school environments - another instance of the structure/agency tension that is a defining characteristic of the experiential social geographies of schooling.

\section{Beyond School Boundaries}

The social geographical importance of schools extends well beyond their physical boundaries. As (typically) long-term institutions, they are sites of common experience within neighbourhoods, which link different generations and provide a physical site for the maintenance of local social contacts. Thus, schools may not only reflect the characteristics of the neighbourhood (e.g. in terms of socio-economic status), but also contribute to building place-based histories and characteristics, and social cohesion. This said, the connection between school and place is not always a positive one - and is, in any case, challenged by neoliberal notions of educational markets and school choice.

\section{SCHOOL COMMUNITIES}

Primary schools, in particular, appear to have the ability to foster a sense of community - they typically serve smaller areas than high schools, elicit greater levels of parental involvement, and function as daily meeting places. Thus, one study of a New Zealand primary school targeted for closure found that it was seen by many parents as 'a hub of family and community life', with the school gate, in particular being 'a valued meeting place for parents; a place to catch up with community news, socialise with other parents, make arrangements for children to play together, and so on' (Witten et al. 2003, 214). Poignantly, for some parents, the school in question 'was the only venue at which they met and talked with other [adults]' (Witten et al. 2003, 214).

Even in communities with greater levels of social capital, and more varied meeting points, schools are often focal points for social interaction and adults' friendship networks, as Butler and Robson's (2001) research in 
three south London neighbourhoods attests. Indeed, in one of those neighbourhoods, a particularly 'successful' primary school was found to be central to the creation and maintenance of social ties, helping to reproduce the local community's 'prosperity and sense of itself' (Butler and Robson 2001, 2149). Interestingly, but perhaps inevitably, such schools receive considerably less official attention than those perceived to be 'failing' their local neighbourhood through weak management, a poor 'ethos', and/or inadequate pupil attainment (Butler and Hamnett 2007).

Admission systems that match pupils to local schools through the creation of 'zones' or 'districts' facilitate strong connections between schools and communities. While sometimes associated with egalitarian visions of education, and the desire to deliver " "equal" state schooling to all communities' (Witten et al. 2003, 207), such zoning can allow schools to reflect, and arguably reinforce, existing patterns of residential segregation along ethnic and socio-economic lines. In this milieu, competition for desirable schools can be played out in the real estate market, with 'selection by mortgage' (Nash and Harker 2005, 209), especially at the high school level (Butler and Robson 2003).

Efforts to disrupt this link between residential and educational privilege have included the comprehensive schools system in the UK (Butler and Hamnett 2007), and desegregation in the USA (Bradford 2006). While school systems can serve as powerful tools for overcoming segregation and social exclusion, they may also perpetuate it through, for example, providing poorer quality education in stigmatized areas, or refusing to admit students from these areas into well-regarded institutions (Warrington 2005). Even where schools are linked to political projects of multiculturalism, breaking the association between residential and educational segregation may be difficult (Johnston et al. 2007; Thrupp 2007).

With the rise of neoliberalism, the logic of school zones has been challenged, and in some instances supplanted, by that of the marketplace. Under neoliberal education frameworks, competition and self-interest are guiding ideals, and parents are, in theory, empowered to choose between a range of schools (Witten et al. 2003). It is typically assumed that in exercising this choice, parents 'will demand of providers and managers better performance that will lead to an overall improvement in educational outcomes' (Butler and Hamnett 2007).

In such scenarios, the spatial contract linking schools and their immediate neighbourhoods has been discarded. With increased choice, parents are 'freed from any "tyranny of place", (Witten et al. 2003, 220) - that is, from the expectation, and effective requirement, that their child will attend the nearest school (at least if they are to benefit from public education). While this enables 'bright children', for example, to escape local schools perceived as inadequate or 'failing', it is - predictably 'middle-class, educationally oriented parents' who are most likely to exercise choice (Butler and Hamnett 2007, 1166). In London, for example, 
relatively prosperous households moving into gentrifying areas where schools remain low-achieving have responded by viewing the whole metropolitan area as a single educational market (Butler and Robson 2003). Less privileged families typically lack the resources (e.g. social capital, flexible employment schedules, private transport) to 'devise and execute the complex strategies' that this entails (Butler and Robson 2003 , 7). Put another way, they are less well placed to undertake the 'work' of choice (André-Bechely 2007).

\section{POLITICAL CONTESTATION}

One of the reasons that schools are so frequently at the centre of ideological projects, and political debates large and small, is that their significance extends beyond contemporary social relationships. Specifically, schooling is thought to have an ongoing influence, shaping the identities and prospects of individuals, and, by extension, families, regions and nations. In addition to imparting skills and knowledges deemed useful or necessary for future adult rules, they also seek to foster particular types of citizenship (Veugelers and Zijlstra 2004). School attendance may also provide a foundation for enduring social networks, facilitating ongoing friendships and future opportunities. Even primary schools may be significant in this regard, connecting children (through their parents) to networks of knowledge that support their transition to 'appropriate' secondary education (Butler and Robson 2003).

The nature of the relationship between schools and the communities of which they are part are also central to many political contests. In the USA, for example, one such contest centred on the proposed introduction of national standards in public schools. For Merrett $(1999,588)$, this debate was a 'struggle over the scale at which education, and hence social reproduction, will occur.' Specifically, increased standardization of education was championed by those who viewed it as necessary for the nation's global economic competitiveness, and contested by those who feared it would entail 'liberal education specialists sympathetic towards multiculturalism . . u usurp[ing] local parental control over value inculcation and social reproduction' (Merrett 1999, 599). In this politics of scale, certain national interests were pitted against demands for greater parental control over school standards. The ultimate devolution of responsibility for formulating and implementing standards to the level of individual states was a partial victory for the latter position, opening the way for myriad regional struggles over curriculum, particularly in matters that are sensitive for religious and/or cultural reasons, such as evolution. Indeed, one survey of state science standards pointed to the problems potentially associated with making such matters subject to the whims of local democracy: only 10 state standards did an excellent or very good job of presenting evolution, while 21 were good or satisfactory, and 19 were unsatisfactory or worse, 
and 'essentially useless for the purposes of teaching evolution' (Lerner 2000, 287).

Debates over teaching evolution point to one of the ways in which schools can be caught up in ideological issues and struggles that originate beyond school boundaries. Ongoing debates around desegregation in US school districts are a case in point, invoking questions that extend well beyond education to encompass racism, affirmative action, community development, the politics of scale, and so on (Bradford 2006). Young people themselves are seldom granted opportunities for meaningful involvement in these debates, or in discussions about school spaces, policies and procedures more generally; instead, they appear as objects in adults' education-related rhetoric.

Given heightened levels of political interest in schooling (Butler and Hamnett 2007), and associated public scrutiny - especially from the empowered middle classes - schools are commonly under pressure to act in ways that mark them out as successful and/or entrepreneurial institutions (Collins and Kearns 2001). Initiatives and reforms which are well received (i.e. interpreted as markers of a school's success) may proliferate and disperse. In the way, innovations may be scaled up from a few innovators to entire educational networks (Veugelers and Zijlstra 2004). Some schools are better placed than others to compete for scarce resources, such as computer hardware (e.g. Holloway and Valentine 2003), potentially contributing to socio-economic disparities, and an increasingly uneven playing field of education (including within the state/public system). Those schools perceived to 'succeed' in this competitive environment may cast long shadows on others nearby deemed less worthy (Fink 2000).

Underpinning such trends is the extension of neoliberal logic of competition to the provision of public schooling. While state-imposed neoliberal reform may manifest in diverse ways within schools (Hargreaves 2002), it is difficult for any one institution to resist neoliberal imperatives in the long term, as Witten et al.'s (2003) study of school closure illustrates. Through the 'marketization' of education, the linkages between schools and their surroundings are being re-written in ways that are consequential for social geography. In addition to the points made about community above, one can note other, perhaps more prosaic changes. One is the increased travel distances experienced by many children, and the emergence of the commuting pupil who leaves home early (perhaps before dawn) to travel across the metropolitan region to a preferred school. This phenomenon - observed in cities from Los Angeles (André-Bechely 2007) to London (Butler and Robson 2003) - underscores the centrality of schools, and parents' educational choices, to children's lived experience. It also, raises questions about children's proscribed agency, especially in urban areas.

Schools are shaped by the characteristics of the district and the nation in which they are located, and, in the context of increasing globalization, 
by the world at large. One of the areas in which this global influence is apparent is in the increasing technological sophistication of the classroom (McGregor 2000), a phenomenon that also illustrates increasing corporate influence over school environments (Hargreaves 2002).

\section{Summary}

Education is a process through which societies express, contest and transform identity, and it is clearly, though complexly, implicated in social reproduction (Lewis 2003). Our focus has been on the social and physical environments in which primary and secondary education is delivered, and their connections to broader social and spatial issues and processes. Notwithstanding the potential for 'hidden geographies' within school boundaries, and for both pupil- and teacher-led contestation of hegemonic approaches and roles, schools can be interpreted as key sites for the reproduction and reinforcement of hegemonic social identities. A basic observation is that schools have often sought to prepare pupils for the role of obedient, respectful, timely and well-presented worker. However, even this observation is open to contestation. Ultimately, whether one interprets public schools as agents for the uncritical reproduction of social norms such as competitive individualism, patriarchy and heterosexism - or as instruments for promoting relativism and progressive politics at the expense of so-called traditional values - is likely to depend on one's broader political/moral compass (Collins 2006; Hunter 1991).

Notwithstanding rigorous and sustained disagreement over the social character and purposes of contemporary education, the notion that schools are sites of preparation for future roles is widely shared. Indeed, this helps to explain their social and political significance - as does the related idea that children have a right, and obligation, to receive formal, specialized preparation for adult life. Accordingly, schools are key sites in many adult debates, and places in which adult-produced ideologies play out.

In addition, one of the primary functions of schools is to separate the young from the material world of adults, particularly from the public and private spaces associated with adult work and, to a (decreasing) degree, travel. One result of this isolation is that schools have become key settings in the lives of young people: they are their work places, and primary sites of social interaction. The organization of school space and procedures has profound influence on their everyday social geographies (as it does also for teachers, and to a degree parents). The regulation of young people's identities, behaviours and bodies within school space remains an enduring topic of interest for geographers and others interested in the sociospatial dimensions of schooling. The isolation of children is by no means complete, however - as recent acknowledgement of the transport flows associated with schools, and school choice, have exhibited (André-Bechely 
2007; Butler and Robson 2003; Collins et al. 2008). These sanctioned, if sometimes problematic, school-related journeys are an important source of mobility for school-aged children; future research might also usefully consider the forms of mobility associated with truancy.

In this article, we have also sought to emphasize that schools are not self-contained places. While they do serve, in part, to isolate young people from broader environments, they also reflect, and contribute to, the communities of which they are part. Accordingly, schools - especially public schools - are places that matter to many (perhaps most?) people; they are sites of common concern that transcend, to various degrees, the social distance associated with class, age, ethnicity and political disposition. Accordingly, in addressing social geographies of education, academics have the potential to engage with issues of broad social and political concern, and to contribute to enduring policy debates about the kind of place the school should be.

\section{Acknowledgements}

We gratefully acknowledge the assistance and encouragement of Jon May and Robin Kearns.

\section{Short Biographies}

Damian Collins is Assistant Professor of Human Geography in the Department of Earth and Atmospheric Sciences, University of Alberta. He was previously a Postdoctoral Fellow at the University of Auckland, New Zealand. He has an MA from Auckland, and a PhD from Simon Fraser University. His research interests centre on the relationship between health and place, and on the geographical dimensions of social, political and land use conflict. Children and young people are a focus for both types of inquiry. Recent work in these areas has been published in Social Science \& Medicine, The Canadian Geographer, and Antipode. Damian's post-doctoral research explored the changing nature of property on the New Zealand coast, where modest holiday homes and campgrounds are increasingly giving way to sumptuous, privatized residential landscapes.

Tara Coleman recently completed a Masters thesis in human geography exploring legislative frameworks around young New Zealanders and their sexuality. It considered the delivery of sexual health messages at school, at home, and within Teen Parent Units, and the ways in which young people and their sexuality are positioned as 'out-of-place' within mainstream society. She teaches in Social Science for Public Health, and in Human Geography, at the University of Auckland. Tara's research interests also encompass the geographies of neoliberalism and the state, interconnections between place and women's health, and public policy analysis. 
* Correspondence address: Damian Collins, Department of Earth and Atmospheric Sciences, University of Alberta, 1-26 Earth Sciences Building, Edmonton, Alberta, Canada T6G 2E3.

E-mail: damian.collins@ualberta.ca.

\section{References}

Aitken, S. (1994). Putting children in their place. Washington, DC: Association of American Geographers.

Allen, L. (2005). Sexual subjects: young people, sexuality, and education. New York: Pelgrave Macmillan.

André-Bechely, L. (2007). Finding space and managing distance: public school choice in an urban California District. Urban Studies 44 (7), pp. 1355-1376.

Andrews, G., and Chen, S. (2006). The production of tyrannical space. Children's Geographies 4 (2), pp. 239-250.

Banks, C. A. (2005). Black girls/white spaces: managing identity through memories of schooling. In: Bettis Pamela, J. and Adams Natalie, G. (eds) Geographies of girlhood: identities in-between. Hillsdale, NJ: Lawrence Erlbaum, pp. 177-194.

Bocking, B. (1995). Fundamental rites? Religion, state, education and the invention of sacred heritage in post-Christian Britain and pre-War Japan. Religion 25, pp. 227-247.

Bradford, M. (2006). Growing up with a community in conflict: the Rockford files. Children's Geographies 4 (3), pp. 277-288.

Butler, T., and Hamnett, C. (2007). The geography of education: introduction. Urban Studies 44 (7), pp. 1161-1174.

Butler, T., and Robson, G. (2001). Social capital, gentrification and neighbourhood change in London: a comparison of three south London neighbourhoods. Urban Studies 38 (12), pp. 2145-2162.

- (2003). Plotting the middle classes: gentrification and circuits of education in London. Housing Studies 18 (1), pp. 5-28.

Catling, S. (2005). Children's personal geographies in the English primary school geography curriculum. Children's Geographies 3 (3), pp. 325-344.

Coleman, T. (2007). Out of place? Young people, education, and sexuality. Unpublished MA Thesis, Geography, University of Auckland.

Collins, D. (2006). Culture, religion, and curriculum: lessons from the 'three books' controversy in Surrey, BC. The Canadian Geographer 50 (3), pp. 342-357.

Collins, D., and Kearns, R. (2001). The safe journeys of an enterprising school: negotiating landscapes of opportunity and risk. Health and Place 7 (4), pp. 293-306.

Collins, D., Bean, C., and Kearns, R. (2008). 'Mind that child': childhood, traffic, and walking in automobilized space. In: McLaren, A. and Conley, J. (eds) Car troubles. Vancouver, Canada: UBC Press, forthcoming.

Collins, D., Kearns, R., and Mitchell, H. (2006). 'An integral part of the children's education': placing sun protection in Auckland primary schools. Health and Place 12 (4), pp. 436-448.

Denham, S. (1999). Part 1: the definition and practice of family health. Journal of Family Health 5, pp. $133-159$.

Dyment, J. (2005). 'There's only so much money hot dog sales can bring in': the intersection of green school grounds and socio-economic status. Children's Geographies 3 (3), pp. 307-323.

Epstein, D., and Johnson, R. (1998). Schooling sexualities. Buckingham, UK: Open University Press.

Fielding, S. (2000). Walk on the left! Children's geographies and the primary school. In: Holloway S. and Valentine, G. (eds) Children's geographies: playing, living, and learning. London: Routledge, pp. 230-244.

Fink, D. (2000). Good school/real school: the life cycle of an innovative school. New York: Teachers' College Press.

Foucault, M. (1977). Discipline and punish: the birth of the prison. New York: Pantheon Books. 
(1980). Power/knowledge: selected interviews and other writings 1972-1977. New York: Pantheon Books.

Hargreaves, A. (2002). Sustainability of educational change: the role of social geographies. Journal of Educational Change 3, pp. 189-214.

Holloway, S., and Valentine, G. (2003). Cyberkids: children in the information age. London: Routledge.

Holt, L. (2003). (Dis)abling children in primary school micro-spaces: geographies of inclusion and exclusion, Health and Place 9, pp. 119-128.

- (2004). Children with mind-body-differences: performing disability in primary school classrooms. Children's Geographies 2 (2), pp. 219-236.

- (2007). Children's sociospatial (re)production of disability within primary school playgrounds. Environment and Planning D: Society and Space 25, pp. 783-802.

Horton, J., and Kraftl, P. (2006). What else? Some more ways of thinking and doing 'children's geographies'. Children's Geographies 4 (1), pp. 69-95.

Hunter, J. D. (1991). Culture wars: the struggle to define America. New York: Basic Books.

Jewett, L. (2005). Power beads, body glitter and backseat bad-asses: girls, power, and position on the school bus. In: Bettis Pamela, J. and Adams Natalie, G. (eds) Geographies of girlhood: identities in-between. Hillsdale, NJ: Lawrence Erlbaum, pp. 35-84.

Johnston, R., Wilson, D., and Burgess, S. (2007). Ethnic segregation and educational performance at secondary school in Bradford and Leicester. Environment and Planning A 39, pp. 609-629.

Lavin, A., Shapiro, G. R., and Weill, K. S. (1992). Creating an agenda for school-based health promotion: a review of 25 selected reports. Journal of School Health 62, pp. 212-228.

Lerner, L. S. (2000). Good and bad science in US schools. Nature 407, pp. 287-290.

Lewis, N. (2003). Geographies of state schooling. Unpublished PhD Thesis, Geography, University of Auckland.

Lynagh, M., Schofield, M., and Sanson-Fisher, R. (1997). School health promotion programs over the past decade: a review of the smoking, alcohol, and solar protection literature. Health Promotion International 12, pp. 43-60.

Mathews, H., et al. (2000). The unacceptable flaneur: the shopping mall as a teenage hangout. Childhood 7, pp. 279-294.

McGregor, J. (2000). Travelling together: teachers meeting the challenge of collaboration. Forum 42 (1), pp. 15-23.

Merrett, C. D. (1999). Culture wars and national education standards: scale and the struggle over social reproduction. Professional Geographer 51 (4), pp. 598-609.

Middleton, S. (1998). Disciplining sexuality: foucault, life histories, and education. New York: Teachers College Press.

Moore, R. L. (2000). Bible reading and nonsectarian schooling: the failure of nineteenthcentury public education. Journal of American History 86(4), pp. 1581-1599.

Nash, R., and Harker, R. (2005). The predictable failure of school marketisation: the limitations of policy reform. In: Codd, K. and Sullivan, K. (eds) Education policy directions in Aotearoa New Zealand. Victoria, Australia: Thompson Dunmore, pp. 201-217.

Newman, M., Woodcock, A., and Dunham, P. (2006). 'Playtime in the borderlands': children's representations of school, gender and bullying through photographs and interviews. Children's Geographies 4 (3), pp. 289-302.

Philo, C., and Parr, H. (2000). Editorial: institutional geographies - introductory remarks. Geoforum 21, pp. 513-541.

Ruddick, J., and Flutler, J. (2004). How to improve your school: giving pupils a voice. New York: Continuum.

Sweet, L. (1997). The controversial issue of religion in Canada's schools. Toronto, Canada: McClelland \& Stewart.

Thomson, R. (1997). Diversity, values, and social change: renegotiating a consensus on sex education. Journal of Moral Education 26, pp. 257-268.

Thomson, S. (2005). 'Territorialising' the primary school playground: deconstructing the geography of playtime. Children's Geographies 3 (1), pp. 63-78.

Thrupp, M. (2007). School admissions and the segregation of school intakes in New Zealand cities. Urban Studies 44 (7), pp. 1393-1404. 
Tranter, P., and Malone, K. (2004). Geographies of environmental learning: an exploration of children's use of school grounds. Children's Geographies 2 (1), pp. 131-155.

Valentine, G. (1996). Angels and devils: moral landscapes of childhood. Environment and Planning D-Society and Space 14, pp. 581-599.

. (2000). Exploring children and young people's narratives of identity. Geoforum 31, pp. $257-267$.

. (2001). Social geographies: space and society. Harlow, UK: Pearson Education.

Van Ingen, C., and Halas, J. (2006). Claiming space: aboriginal students within school landscapes. Children's Geographies 4 (3), pp. 379-398.

Veugelers, W., and Zijlstra, H. (2004). Networks of schools and constructing citizenship in secondary education. In: Hernandez, F. and Goodson, I. (eds) Social geographies of educational change. Dordrecht, The Netherlands: Kluwer Academic Publishers, pp. 65-78.

Warrington, M. (2005). Mirage in the desert? Access to educational opportunities in an area of social exclusion. Antipode 37 (4), pp. 796-816.

Witten, K., et al. (2003). Educational restructuring from a community viewpoint: a case study of school closure in Invercargill, New Zealand. Environment and Planning C-Government and Policy 21, pp. 203-223.

Woolley, H., et al. (2006). Going outside together: good practice with respect to the inclusion of disabled children in primary school playgrounds. Children's Geographies 4 (3), pp. 303-318. 